\title{
COMBINED ANNUITY AND SINGLE PREMIUM LIFE INSURANCE UNDER THE ESTATE TAX: EFFECT OF ASSIGNING THE INSURANCE*
}

AGE and physical condition often preclude elderly persons from obtaining life insurance. ${ }^{1}$ But many insurance companies offer to sell such individtuals single premium policies without a medical examination on a condition which distinguishes such policies from orthodox insurance: the insured must relieve the company of the risk of early death by the simultaneous purchase of an annuity. ${ }^{2}$ Although the single premium for the insurance part of sttch a

* Bohnen v. Harrison, 199 F.2d 492 (7th Cir. 1952), cert. granted, 21 U.S.L. WEEK 3233 (U.S. Mar. 9, 1953).

1. All companies have age limits beyond which they will not issue ordinary life insurance despite medical fitness. Prudential Life Insurance Company of America, for example, has an age limit of seventy.

2. The following companies issue combination single premium life insurance and life annuity policies without medical examination:

$\begin{array}{lcc} & \begin{array}{c}\text { Ratio of Total } \\ \text { Premium to Insurance } \\ \text { Face Value }\end{array} & \begin{array}{c}\text { Matimimm } \\ \text { Total } \\ \text { Premium! }\end{array} \\ \text { American National } & \text { variable } & \$ 50,000 \\ \text { Columbian National } & 110 \% & 10,000 \\ \text { Continental Assurance } & 110 \% & 110,000 \\ \text { Dominion Life } & 110 \% & 110,000 \\ \text { Equitable, Iowa } & 110 \% & 55,000 \\ \text { Great-West } & 107 \% & 133,750 \\ \text { Life of Virginia } & 108 \% & 54,000 \\ \text { Manhattan Life } & 110 \% & 55,000 \\ \text { Manufacturers } & 108 \% & 200,000 \\ \text { Occidental, California } & 107 \% & (\text { a) } \\ \text { Ohio National } & 110 \% & 27,500 \\ \text { Pan-American } & 110 \% & 55,000 \\ \text { Prudential } & 110 \% & 220,000 \\ \text { United States Life } & 110 \% & 55,000\end{array}$

(a) $\$ 25,000$ insurance plus the annuity.

From Who Writes What (1952), a standard insurance reference.

These combinations have achieved considerable popularity. Prudential, for example, had 1,694 of these contracts in force on September, 1952, providing insurance totaling $\$ 31,209,818$. Communication to the Yale LAw Journal from James V. Hughes, Manager of the General Actuarial Division, Prudential Life Insurance Company of America, dated December 5, 1952, in Yale Law Library.

Some ordinary life insurance is also written without a medical examination. Mactean, Iffe Insurance 255-8 (7th ed. 1951).

For discussion of the difference between annuities and life insurance, see Cohen, Annuities and Transfer Taxes, 7 KAN. B.A.J. 139 (1938) ; Note, 26 VA. L. REv. 230 (1939).

In VANCE, INSURANCE $\$ \S 1,10$ (3d ed. 1951) the contract of insurance is defined largely in terms of "risk," which is designated as one of th essential elements of an insurance contract. The insurance-annuity combination involves some risk, but not of an insurance nature; rather it is an investment risk-that incident to the management and investment of the insured's funds. 
combination purchase is below the face amount of the policy,3 the difierence is more than made up by the amount paid for the annuity. In fact, total premiums paid for the combination usually equal about one hundreil ten percent of the face value of the insurance policy. If the insured dies liefore the insurance premium plus accrued interest equals the face value, the procests of the policy are paid partly from the unused balance uf the annuigy innt."

Because the insurance-annuity combination thus differs from urthulu: insurance, problems have arisen as to whether it should be treated as "insurance" for purposes of the federal estate tax. ${ }^{\circ}$ In 1941, when life insurance proceeds up to $\$ 40,000$ could be excluded from a decedent's gross estate," the Supreme Court in Helvcring $z$. Le Gicrses decided that the insurance part of such a combination was not "insurance" within the meaning of that statute. Indicating that the policy of the exemption was to promote insurance contracts which protect beneficiaries against the financial risk of the early death of those who support them. the Court found that such an element was absent from the combination. Since the presence of the annuity removed all elements of insurance risk, ${ }^{9}$ the Court viewed the combined purchase as a "single investment" 10 and declared the exemption inapplicable."1

3. For an explanation of how net single premiuns are cumputed, sse MAches: obs cit. supra note 2 , at $96-101$.

4. For list of companies see note 2 supra.

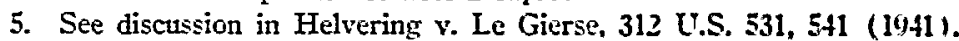

6. For discussion of some of the tax problems, other than the one considered by this Note, raised by the insurance-annuity combination and by annuities in general, sce Meisenholder. Tazation of Anmuity Contracts l'nder Estate and Inheritance Tases, 39 Mich. L. Rev. 856 (1941).

7. "The value of the gross estate ... shall be determined by incluling the value... of all property ... [t]o the extent of the amount receivable by the exccutor as insuranice under policies taken out by the decedent upon his own life: and to the extent of the excess over $\$ 40,000$ of the amount receivable by all other beneficiaries as incurante under policies taken out by the decedent on his own life." Revenue Act of 1926 , $\$$ 302(g), 44 STAT. 70 (1926), 26 U.S.C. $\$ 411$ (g) (1935).

The first of these insurance-annuity combinations before the courts was one unit-a life annuity with a lump sum payable at death. That combination was denied the esemption because the necessary insurance risk was absent and it was considered as an investment with income reserved for life and with a remainder to the bancficiaries. Old Colony Trust Co. v. Commissioner, 102 F.2d 380 (1st Cir. 1939).

S. 312 U.S. 531 (1941). Estate of Keller v. Commissioner, 312 C.S. 543 (1941), and Tyler v. Helvering, 312 U.S. 657 (1941), dealing with the same Iroblem, were decided the same day as Le Gierse.

9. See note 2 sispra.

10. "Investment" is used here in the colloquial sense by which stucls and homb are termed investments while insurance is not. Functionally, however, life in urance in cons-

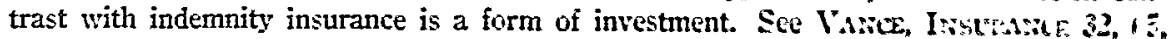
101, 105 (3d ed 1951). Although the terminology may thus be inast, the distinztion is nevertheless a valid one. The exemption (see note 7 surro) applicil specifically ty "insurance"; it seems appropriate to have denied that exemrition to uther nis dey of saving "investments" which lacked the essential elements of insurance.

11. "To say they are distinct transactions is to ignore actuality... [They] iait to spell out any element of insurance risk:" Helvering v. Le Gierse, 312 C.S. 531, 5iu-1 
The exemption for insurance was removed from the estate tax in $1942 ;^{12}$ hence no estate tax problem is now presented by the insurance-annuity combination so long as the insurance ${ }^{13}$ is the property of the insured at death. The full proceeds of the insurance part of the combination will be included in the gross estate of a decedent whether the package be considered insurance or an investment. ${ }^{14}$ But when by irrevocable assignment the insurance policy has been separated from the annuity, ${ }^{15}$ the Le Gierse holding that the combination is not insurance troubles courts forced to decide whether to include the proceeds of the insurance in the gross estate of the insured. Taking the position that they cannot apply established criteria for handling orthodox insurance, ${ }^{10}$ the courts undertake an analysis of the policy as an "investment."

In 1946 the Second Circuit in Burr v. Commissioner ${ }^{17}$ included the insurance proceeds in the decedent's estate although the policies had previously been irrevocably assigned to certain beneficiaries. ${ }^{18}$ The clecedent purchased the

(1941). Insurance contemplates shifting the economic risk of death to the insurer. When a combination policy is purchased, the insured himself covers that risk by buying the annuity.

12. The provision exempting the first $\$ 40,000$ was omitted from the Revenue Act of 1942.

13. For the sake of convenience, this Note will continue to call the insurance part of the combination "life insurance," even though it may not technically qualify as "insurance" under the Le Gierse ruling.

14. The proceeds would be includible as property owned by the decelent at death under INT. REv. CODE $§ 811$ (a).

15. Under an irrevocable assignment all the legal incidents of ownership may be transferred. These include: the right to the economic benefits of the policy; the power to change the beneficiary; to surrender, cancel or assign the policy; to rcvoke an assignment; to pledge the policy for a loan, or to obtain a loan against the cash surrender value of the policy. See U.S. Treas. Reg. 80, art. 25 (1934).

16. From 1919 to 1942 INT. REv. CoDE $\S 811(\mathrm{~g})$ included in the estate the face value of policies "taken out by the decedent upon his own life." The Treasury Department, in part to appease the courts, inconsistently utilized two tests in determining whether a decedent had "taken out" a policy within the statutory meaning. One test measured includibility by whether the decedent paid the premiums; the other tests, by whether the decedent held "incidents of ownership" after the policy was transferred. For detailed descriptions of the antics of the Treasury in this connection, see Eiscnstein, Estate Taxes and the Higher Learning of the Supreme Court, 3 TAX L. REV. 395, 514-21 (1948); Schlesinger, Taxes and Insurance: A Suggested Solution to the Uncertain Cost of Dying, 55 Harv. L. Rev. 226, 230 (1941). The last Treasury Decision before the 1942 amendment removed the "taken out by the decedent" language, abandoned the incidents of ownership test. Insurance henceforth was to be includible if the decedent paid the premiums. T.D. 5032, 1941-1 CuM. BuLL. 427.

INT. Rev. CoDE $\S 811(\mathrm{~g})(2)$ specifies the criteria to be used today. See notes 27, 28 infra.

17. 156 F.2d 871 (2d Cir. 1946), cert. denied, 329 U.S. 785 (1946).

18. Estate of Cora C. Reynolds v. Commissioner, 45 B.T.A. 44 (1941), was the first case dealing with the general problem. The transferred policy was included in the decedent's estate as a transfer designed to take effect at death and in which the decedent had reserved a life income. In that case the policy was transferred to trustees. 
combination when he was seventy-five. Shortly after the purchase, he made the transfer and paid a gift $\operatorname{tax}^{19}$ But the court considered the combination indivisible for estate tax purposes. Basing its decision on the Le Girrse rationale that this was a single investment, it found that the annuity payments constituted income from the entire investment pacliage. Since the court felt that the decedent had reserved that income to himself for life, the arrangement was likened to an annuity with a life estate retained and with a remainder to be transferred at death. Thus it was held includible under Internal Revenue Code Section 811 (c)(1)(B), which taxes as part of the estate transfers of property the income from which is reserved to the grantor for life. ${ }^{20}$ In February, 1952, the Sixth Circuit in Coniay 2. Glen $^{21}$ followed Burr in an indistinguishable fact situation.

On the other hand, the Seventh Circuit in Bolnen a. Harrison 20 recently held on facts almost identical to Burr that such irrevocably assigned insurance was not includible in the insured's estate. Mrs. Bohnen purchased the combination when she was sixty-two years old. Immediately after the purchase she assigned all her rights in the insurance policy to certain beneficiaries and paid a gift tax on the transfer. ${ }^{23}$ The Seventh Circuit, affirming the district court's judgment for the taxpayer, ${ }^{24}$ held that the insurance was separable from the annuity and that the assignment touk the policy pruceds out of the decedent's estate. The court also ruled that the income re:erverl by retention of the annuity was traceable to the annuity only and not to the whole investment. The Bolnnen court, therefore, squarely rejected Burr's

19. The valuation of a one-premium life insurance policy for the giit ta: is the cost at the time of the gift of acquiring a similar policy. U.S. Treas. Rer, 108. $\$ \$ 6.19(i)$ (1943). This is so even though the cash surrender value is smaller. Guggenheim $v$. Rasquin, 312 U.S. 254 (1941). The same basis for valuation is applied to a gift the insurance part of an insurance-annuity combination, despite the fact that there is no ordinary insurance risk and the purchase of the annuity was required for jurchace of the insurance. Letter of Deputy Commissioner D. S. Bliss, March 27, 1941, CCH FEv. EST. \& GIFT TAX REP. If 5478.55 (1946). The annuity purchase was merely a condition precedent to the purchase of the insurance, and not part of the consideration for the insurance.

The gift tax paid on a transfer which is later included in the estate may be credited against the estate tax. INT. REv. CODE $\$ \$ 13(a)$.

20. Burr v. Commissioner, 156 F.2d 871,872 n.1 (2d Cir. 1946). I:s. Rev. Cors $\S 811$ (c)(1)(B) includes in the estate transfers "under which [the decedent] has retained for his life or for any period not ascertainable without reference to his death or for any period which does not in fact end before his death ... the possession or enjoyment of, or the right to the income from, the property. ..."

21. 193 F.2d 965 (6th Cir. 1952).

22. 199 F.2d 492 (7th Cir. 1952), cert. granted, 21 U.S.L. WEEk 3233 (U.S. Mar. 9, 1953).

23. See note 19 supra for discussion of valuation of the transferred insurance for the gift tax.

24. Bohnen v. Harrison, 100 F. Supp. 118 (N.D. Ill. 1951). The district court based its decision on the fact that there had been no retained reversiunary intcrest as there had been in Goldstone v. United States, 325 U.S. 687 (1945). 
rationale and its extension of the Le Gierse doctrine; but the court accepted the conclusion that the insurance-annuity transaction constituted an "investment" rather than insurance. On March 9, 1953, the Supreme Court granted certiorari.

The Bolnen opinion appears justified in rejecting Burr's application of Le Gierse. Le Gierse dealt only with the question of whether the insurance part of the combination was insurance within the purview of the estate tax exemption. No assignment had been made, and it was conceded that the whole package was includible unless exempt as insurance. ${ }^{25}$ The Lc Gicrsc holding that the combination was a single investment when purchascd does not preclude a later splitting of that investment by assignment of the life insurance. ${ }^{26}$

The Le Gierse ruling could be restricted further and held wholly inapplicable to the type of question presented in the Burr, Conzeay, and Bolnten cases. In Le Gierse the Supreme Court pointed out that the exemption under consideration was designed to protect insurance contracts, which-by distributing losses-guard individuals against the risk of the premature death of those upon whom they depend for support. The policy behind Le Gicrse, therefore, seems to be a recognition that protection of such persons is not furthered by the insurance-annuity combination, which in fact involves no distribution of individual losses. But such social policy provides no basis for distinguishing the assigned insurance portion of a combination from assigned orthodox insurance in order to include it within the gross estate under Section $811(\mathrm{c}){ }^{27}$ In the hands of assignees, both policies would be precisely the same. And identical treatment for the policies in no sense wottld permit taxpayers to defeat any legislative policy geared to the special "insurance risk" nature of the transaction. Present legislative policy is designed to include almost all insurance in the gross estate. But assigned insurance is included in the gross estate only if the decedent had "incidents of ownership" in the policy either at death or after January 10,1941, whichever was earlier", or if he originally took out the policy on his own life after that date. ${ }^{28}$ In

25. Helvering v. LeGierse, 312 U.S. 531, 537-8 (1941).

26. The annuitant's rights are also assignable in the absence of a condition to the contrary in the annuity contract. RESTATENENT, Contracts $\$ \S 151,155$ (1932). In the Burr case, for example, the annuity was assignable. Transcript of Record, p. 28, Burr v. Commissioner, 156 F.2d 871 (2d Cir. 1946).

27. According to INT. REv. CODE $\S 811(\mathrm{~g})(2)$ the value of the gross estate is determined by including proceeds of life insurance "receivable by . . . other beneficiarics ... [and] purchased with premiums ... paid ... by the decedent, in proportion that the amount so paid by the decedent bears to the total premiums paid for the insurance ... or with respect to which the decedent possessed at his death any of the incidents of owncrship, exercisable either alone or in conjunction with any other person."

28. Section $811(\mathrm{~g})$ of the Code is to be applied as provided by $\S 404(\mathrm{c})$ of the Revenue Act of 1942:

"The amendments ... shall be applicable only to estates of decedents dying after the date of the enactment of this Act [October 21, 1942] ; but in determining the propor* 
those limited situations where insurance is still excluded from the gross estate, therefore, the exclusion is based entirely on the fact of assignment. By surrender of the "incidents of ownership" of the policy, the decedent is considered to have made a present gift of the policy, with no economic interest passing at his death. ${ }^{29}$ Thus in Bohnen the Suprene Court could, withut logical inconsistency, distinguish $L \ell^{\prime}$ Gicrsc: it could continue to treat the insurance-annuity combination as failing to contain those elements of "insurance risk" needed to qualify for the pre-19+2 insurance exemption; at the same time, it could handle the assigned insurance portion of the combination in the same manner as orthodox insurance for the purpose of determining whether it should be included in the gross estate under Section 811 (g)(2) (A). Under the facts of the Bohnch case, such treatment as true insurance would probably lead to exclusion of the proceeds from the gross estate. But it would provide a far more realistic and workable solution to the tax problem raised by the combination than present tortuous attempts to fit the transaction into an "investment" category.

The Burr rationale that the annuity payments represent income from the total investment appears highly unrealistic. The annuity could have licen purchased alone-even though the insurance could nut have leen purchased without the annuity-and the income therefrom wull have been the sane." And if the insurance policy had been cashed in by the beneficiaries, no change would have resulted in the annuity payments. ${ }^{31}$ In vieving the cxistence of the power to cash in the policies as immaterial because unexercised, Lumr iailed to consider the significance of the inmutability of the annuity jayments ats evidence of their source.32 Further evilence of the indepentence of the

tion of premiums paid ... by the decedent ... the amount so paid . . on or biore January 10, 1941 [the effective date of T.D. 5032, 1941-1 cirs. BCLn 437], shall is excluded if at no time after such date the decedent possessed an imcidunt of unnersiny in the policy."

According to U.S. Treas. Reg. 105, \$ 81.27 (1943) if the decdent died on or lisfort October 21,1942 the excess of such insurance over $\$ 40,000$ is included: "To the estent to which such insurance was taken out by the decedent upon his own life after January 10,1941 , and ... [t] the extent to which such insurance was taken out by the deredint upon his own life on or before January 10,1941, and with respect to which the dercdent possessed any of the incidents of ownership ... after such date, or, in the case wi a decedent dying on or before such date, at the time of his death."

29. Ballard v. Helburn, 9 F. Supp. $812,814,815$ (W.D. Ky. 1933), aff'd, 8511.21 613 (6th Cir. 1936). See also Flick's Estate v. Commissioner, 160 F.2d 733 (5th Cir. 1948).

30. The annuity and the life insurance are treated as independent contracts by the insurer. The premiums are the same as if the policies were purchased separately. The reserves are calculated separately. Each is a single independent contract on its iace. See Meisenholder, Taxation of Ammity Contracts tnder Estate and Inhcritance Torcs, 39 Mrch. L REx. 856, \&S3 (1941). See also Conway v. Glenn, 97 F. Sugp. 331, 332 (W.D. Ky. 1951).

31. Meisenholder, supra note 30 , at $\$ \& 3$.

32. Burr declared the combination to be "analogous to a simple annuty with yrinciual payable at death," citing Commissioner v. Clise, 122 F.2d 998 (9th Cir. 1941), cert. 
annuity payments from the insurance is the fact that the dividends from the insurance policies themselves were paid directly to the beneficiaries as holders of the policies without regard to the ownership of the annuity. ${ }^{33}$ Moreover, when this question was raised in an income tax context the payments were held to derive only from the annuity and not from the whole investment. ${ }^{\text {a4 }}$

Closeted in the conclusion that income was retained from the whole "investment," Burr did not find significant the fact that a gift of real value was

denied, 315 U.S. 821 (1942), and Commissioner v. Wilder's Estate, 118 F.2d 281 (5th Cir.), cert. denied, 314 U.S. 634 (1941), as support for the taxability of such annuitics to the estate. Burr v. Commissioner, 156 F.2d 871, 872 (2d Cir. 1946). The Clist case, however, concerned "joint and survivor non-participating annuity contracts" and not an annuity with principal payable at death. Wilder also concerned survivorship annuities.

The annuity with principal payable at death is the kind considered in Old Colony $v$. Commissioner, 102 F.2d 380 (1st Cir. 1939). See Note 7 supra. Such an annuity is not divisible for surrender purposes because the contract is one unit. See Meisenholder, supra note 30 , at 884 . By contrast, the insurance-annuity combination may be divided and the insurance surrendered. See note 30 supra.

There are also refund and cash refund annuities. Under the refund annuity, the insurer continues payments on the annuity after the annuitant's death until the total payments equal the original purchase price. The cash refund type of annuity contract provides that at death the excess of original premium paid over total annuity payments will be paid immediately in cash. Such annuities give a lower yield than the straight life annuities where there is no refund and payments terminate at death. MACLEAN, op. cit. supra note 2 , at 51-2.

33. In fact such payments are not "dividends" in the same sense as dividends paid on corporate stocks. They are merely an adjustment of the premium cost. Wecks v. Commissioner, 16 T.C. 248, 255 (1951) ; MACLEAN, op. cit. stipra note 2, at 158-87.

34. In one case the Commissioner tried to tax as income the amount antually received from the investment. The Tax Court held that under $\$ 22(\mathrm{~b})(2)$ (A) only the amount calculable as interest on the purchase price of the amnuity was taxable as income-the rest being recognized as a return of capital-and that the component parts of the investment should be regarded separately in determining the receipts attributable to each. Koehrer v. Commissioner, 4 T.C.M. 219 (1945). Cf. Helvering v. Mercdith, 140 F.2d 973 (8th Cir. 1944) (annuity payments taxed as annuities under $\$ 22$ (b) (2) (A) and life insurance dividends not taxed until they exceed aggregate premiums paid).

INT. REv. CODE $\S 22(\mathrm{~b})(2)(\mathrm{A})$ provides: "Amounts received as an annuity . . . shall be included in gross income; except that there shall be excluded . . . the excess of the amount received in the taxable year over an amount equal to 3 per centum of the ... premiums ... until the aggregate amount excluded ... equals the . . . premiums. . . ." The same section also excludes amounts received as dividends from an insurance policy until such payments exceed the premiums paid.

This section recognizes the fact that annuity payments represent a return of principal with interest. The $3 \%$ figure is used because it is assumed that at least that much of the return represents interest and therefore should be taxable income. U.S. Treas. Reg. $111, \S 29.22$ (b) (2)-2 (1943). The tax in effect seems to be a $6 \%$ tax because figured each year on the basis of the original premium, part of which is consumed each year. Sec Comment, 11 TEASP. L.Q. 567, 568 (1937).

Under U. S. Treas. Reg. 105, \& 81.18 (1942), when a transferor retains the inconte from a part only of transferred property only "a corresponding portion of the value of the property should be included." It would seem, therefore, that under this regulation the insurance proceeds are not includible. 
completely transferred before the death of the insured. The insured received no income from the transferred insurance policies, since the only distributed income was represented by the insurance dividends, which the beneficiaries received. Nor did he retain any reversionary interest. ${ }^{35}$. And no additional powers over the original gift passed to the beneficiaries by reason of the transferor's death. ${ }^{36}$ The inclusion of the transferred portion of the "investment" under Section 811 (c)(1)(B) ${ }^{37}$ therefore seems unwarranted. The transfer was merely one way of making a gift that could have been in cash. If this had been done no estate tax issue would have arisen and the gift would have been subject only to the lower gift tax even under the Burr reasoning. ${ }^{3 s}$.1 similar amount might also have been transferred by giving property outright of the same value. Moreover, if the transferees had exercised their power to cash in the life insurance policies they would have been in the same position as if they had initially received cash. So long as the insurance pruceeds are viewed as part of an "investment," there seems to be no valid reasun for penalizing those transferees who do not elect immediately to realize the present cash value of the investment transferred to them.

Although the Burr "investment" analysis therefore appears erroneous in view of the factual nature of the transaction involved, Bolncn's holding that all the proceeds of the insurance policy paid at death are completely exempt is also open to objection. The Bolnnen court looked exclusively at the techniques of the transaction. Noting that the insurance and the annuity

35. In Goldstone v. United States, 325 U.S. 687 (1945), the transferor reserved the right to the return of the policies if he survived the beneficiaries. Pointing out that this was not insurance under the $L_{e}$ Gierse ruling, the Court held it includible in the gross estate as a transfer "intended to take effect in possession and enjoyment at ... death." The Court decided the question merely on the basis of the decedent's possession of the reversionary interest; it found it unnecessary to reach the question of whither or not there was retained income-the problem which the courts discussed almost exclusively in the Burr, Conziay, and Bolmen cases.

36. The gift had a value when transferred, and the transferor's death in no way affected that value. The fact that death resulted in an addition to the original gift did not change the beneficiaries' power over the original gift.

Even after the policy matures at death, it may be left intact with the company which will pay interest thereon. MIAciEAN, op. cit. supra note 2, at 583-7. In that case, the policy must still be "cashed in" in order for the beneficiaries to realize its value-just as the policy could have been cashed in prior to death to realize the value of the original gift.

37. For text of section, see note 20 sitpra.

38. The federal gift tax rate is only about three quarters of the estate tax rate. Although the difference was originally explained on the basis of the fact that the tases were enacted at different times, many subsequent reasons have been given. The present rate was first enacted in 1932. Some thought the lower rate would encourage the transier of personal wealth during life. See Representative Crisp's remarks of Miarch 10, 1932, in 75 CoNG. Rec. 5691 (1932) ; Harriss, Legislative History of Federal Gift Tazation, 18 TAXes 531, 536 (1940); Magill, The Federal Gift Tax, 40 CoL L. REv. 773, 776, 791 (1940). 
were independently handled, it excluded all proceeds from the estate. But such treatment does not take account of the fact that the donees at the insured's death received a second gift-measured by the difference between the value of the policy just prior to death and the face value.

Within the framework of the present policy of refusing to treat the insurance part of a combination purchase as "insurance," a better approach than either Burr or Bohnen would include in the decedent's estate that part of the insurance proceeds which the beneficiaries actually receive as a result of death. Such an amount could be included under Section 811 (c)(1)(C) of the Code, which taxes as part of the estate transfers "intended to take effect . . . at . . . death." Neither Burr nor Bohnen, which rested on an interpretation of Section 811 (c) (1) (B), ${ }^{39}$ considered that provision. Yet a reasonable view of the transaction seems to place it within the scope of that section. As the annuity payments are made, decreasing the annuity principal, the lump sum insurance premium held by the insurance company increases in value through investment earnings. The increase in the cash surrender value of the policy reflects this rise in value. ${ }^{40}$ At death the annuity payments cease and the face amount of the insurance policy is paid to the beneficiaries. The difference between the value of the original insurance premium plus accrued interest just before death and the face value of the policy is covered by the remaining annuity principal. ${ }^{41}$ The initial gift of the policy could be viewed as the transfer of a liquid security which might be converted into cash at any time before cleath. And the annuity could be considered as a trust from which the settlor reserves yearly payments for life, with the remaining corpus to be used to pay the face value of the insurance policy if the policy is not converted before the settlor's death. Thus regarded, the original gift would not be included in the estate because it is complete before death and enjoyment can be realized at any time by surrender of the policy; the trust-measured by the difference between the cash surrender value of the policy just before death and its face value $\mathbf{4 2}$

39. For text of section, see note 20 supra.

40. For some time after an insurance policy is first written the cash sturrender value is lower than the original lump sum premium because of the "loading factor"-the amount added to the net premium to cover the cost of administration, and to give a surplus for unanticipated losses. VANCE, Insurance 67 (3d ed. 1951); see also KNIGuT, ADVANCEn LifE InSURANCE, 127-46 (1926). For an example of how the cash surrender value rises yearly see Transcript of Record, p. 23, Burr v. Commissioner, 156 F.2d 871 (2d Cir. 1946).

41. This is true at least in the situation where the decedent does not outlive his life expectancy. If he lives "too long," of course, no annuity principal will remain-since it will have been consumed by the annual payments. The essential point, however, for the Le Gierse decision is that the initial risk of the insured dying soon was eliminated by the purchase of the annuity. After many years, when the annuity principal is gonte, the investment earnings of the insurance policy will have made up the difference between the insurance premium and its face value.

42. The cash surrender value should be the value used for the tax purpose here because that is the only value actually realizable to the assignees. Unfortumatcly this 
-would be included, however, for that is the economic interest which shift: to the beneficiaries as a result of death and so falls within the terms of Section 811(c) (1)(C).

Should the Supreme Court in deciding Bolncn accept the view that Le Gierse precludes it from treating the assigned policy as insurance, the Court would face at least three alternatives in handling the transaction under Section 811(c) : it could affirm the Seventh Circuit's holding that none of the proceeds are includible in the gross estate; it could reverse the Seventh Circuit and adopt in toto the rationale of the Burr opinion; or it could attempt to split the proceeds so as to include within the estate only that real economic interest which actually passes at death to the beneficiaries. Within an investment rationale, the last approach appears most closely in harmony with the factual realities of the case. But all involve a difference in ta: treatment between assigned orthodox insurance and assigned purtion of an insurance-annuity combination that is, perhaps, unwarranted.

The Court also has the alternative of distinguishing Le Gicrse and handling the combination in Bolinen as true insurance under Section $811(\mathrm{~g})$. The sole reason for presently denying such treatment appears to be Le Gicrse's previous determination that the combination in the hands of the purchaser at death should be denied special tax advantages then given by Congress for the purpose of stimulating the purchase of orthodox insurance. Since that public policy justification is applicable only to the special pre-1942 insurance exemption and is absent where the question merely involves proper treatment of the assigned insurance portion of a combination, this $811(\mathrm{~g})$ solution appears most equitable.

might involve a double tax on the difference between the cash surrender value at death and the value upon which the gift tax was paid since the cash surrender value at death might still be lower than the gift tax basis. For explanation of gift tax evaluation sce note 19 supra; for full explanation of cash surrender value basis, see VArce, Insurasice 73-4 (3d ed. 1951). Some credit, however, may be allowed for the gift tax raid. Irit. REV. CODE $\$ \$ 13(\mathrm{a})$. 